\title{
Fifty Years Young: Library of Congress Cards
}

Mr. Walter is chief, Card Division, Library of Congress.

$\mathrm{E}^{\prime}$ VERY UNIT of the Library of Congress is in some particular way, directly or indirectly, a servant of the Congress, the government, and the people of the United States. But it is the service of the Card Division, authorized by an act of Congress just fifty years ago, which is at the fingertips of the people in the Tarkios, the Chillicothes, the Opelousas, and the Peshtigos throughout the whole of this broad land. In these, and nearly 9,000 other towns, millions of Americans every year thumb through the LC $3 \times 5$ cards to select the literature they may choose.

Could the librarian of historic Plymouth, Massachusetts, or the more youthful Beaver, Utah, fulfill the myriad responsibilities of community life and also classify each library volume in accordance with the most exacting canons of library science? That is indeed a rhetorical question, for reliance on the LC catalog card to perform this function has become a part of the pattern of our national life within the past two score years and ten.

Great and growing cities in 1896 were confronted with the cataloging problem on a different scale. Melvil Dewey, a distinguished figure in the library world and then the secretary of the University of the State of New York, declared: "We have, perhaps, 4,000 public libraries in the country of $\mathrm{I}, \mathrm{OOO}$ volumes or more. If a book is published that 500 of these libraries will buy, where can you think of a greater waste than that everyone of the 500 should have to undertake, each for itself . . . to catalog that book when it has been already cataloged in the National Library by the most expert staff in the country. ... Printing is very cheap. Any library willing to pay the cost of paper and postage could have a copy of these cards furnished without extra expense to the government, which has already paid for making its own cards." Herbert Putnam, the librarian of the Boston Public Library, felt the Library of Congress should take the responsibility for serving the American libraries in many ways.

One of his beliefs was that libraries throughout the country should derive some benefit from the expert cataloging done at the Library of Congress.

In 1899, when Mr. Putnam became librarian of Congress, immediate steps were taken to make printed cards available to libraries and institutions.

Announcement of the new service was first made on October 28, 1901 when the library issued a three-page leaflet under the heading: Distribution of Catalogue Cards. It was pointed out that the Library of Congress was prepared to furnish copies of the cards it was printing for books in its own collection. At that time cards were being printed for books copyrighted under the laws of the United States, for miscellaneous material, and for printed books in the collection as they were reached in the process of reclassification. The subscription price was based on the cost (including handling) 
of the extra copies printed, plus 10\%. The number of copies of the same card ordered at the same time had a bearing on the subscription price. In any case, the cost of a single copy of a single card was not to exceed two cents. Orders for cards were accepted in any form that specifically identified the book. For copyrighted books it was suggested that a subscriber check a copy of the Weekly Bulletin of copyright entries. The Bulletin at that time was a publication issued by the Treasury Department and was sold at $\$ 5.00$ per year. As the Publishers' Weekly contained almost all the titles that would interest the ordinary library, a checked copy of that publication was acceptable in ordering cards.

Still another way of ordering cards was by using the proof sheets or galley strips printed for the cards. These strips were sent to libraries ordering, or who were likely to order, a considerable number of cards. On the proofs each title received a consecutive printer's number. The sheets could be cut and the titles desired forwarded as an order. Because of the printer's number, it was possible to order by number alone. Subscribers were unable to determine whether their orders reached the library in advance of printing, hence they could not determine the precise amount to send with their orders. To remedy this situation, the following courses were devised: first, if libraries remitted with each order, the remittance was to cover the higher charge (two cents for the first copy; five-tenths of one cent for each additional copy), and any balance was credited; and second, an advance sum could be deposited with the Librarian of Congress. Any cards purchased were debited against the account.

The task of organizing the Card Distribution Service fell upon the shoulders of a clerk in the Catalog Division, Charles Harris Hastings. He was first employed by the library to cut up the older book form catalogs and to mount the clippings on standard size cards. On those cards, he penciled in the old shelf numbers and filed the cards in the new catalog for the public, where many of them may still be found. Mr. J. C. M. Hanson, then chief of the Catalog Division, stated that Mr. Hastings took his task so seriously and made such headway that, when the Card Section was organized in I90I, he had little hesitation in recommending $\mathrm{Mr}$. Hastings for the new position of chief of the Card Section of the Catalog Division.

The cards mentioned above have become the standard size of approximately $3 \times 5$ inches $\left(261 / 64\right.$ th $\times_{4} 59 / 64$ th inches, to be exact). Only first quality, Ioo per cent rag stock is used. Thus the durability of the cards and of the catalogs which they form is insured.

The initial experiments proved so successful that in 1902 Congress provided that "The Librarian of Congress is hereby authorized to furnish to such institutions or individuals as may desire to buy them, such copies of the card indexes and other publications of the Library as may not be required for its ordinary transactions, and charge for the same a price which will cover their cost and ten per centum added, and all moneys received by him shall be deposited in the Treasury" ( 32 U.S. Statutes at Large, I30I). This is the statutory basis for the Card Division as it exists today.

The first year of the Card Distribution Service, operating under the Statute of 1902, brought into the Treasury of the United States \$3,785.19 from the sale of cards. Two hundred and twelve subscribers were listed in the records of the Card Section. By I910 the subscriber list had grown to 1366 and cash sales of cards and proofsheets that year amounted to $\$ 28,498$.o9. In fiscal 1920 the number of 
subscribers to the printed cards had increased to 2877 and sales totaled $\$ 77,155.86$. In 1930 the subscriber list numbered $501 \mathrm{I}$ and a total of $\$ 242,580.5 \mathrm{I}$ was realized from the sale of cards. By 1950 the number of subscribers had grown to 8947 who purchased 21,594,989 printed cards. The total revenue from the sale of cards and related technical publications in 1950 amounted to \$1,025,251.99.

The expenditure to produce these cards is, of course, a large one. But the cost of separately cataloging each item independently by thousands of libraries would be several times as much. Thus the saving in dollars alone by the libraries of this country amounts to millions of dollars annuallyeven if the quality of the cataloging were not considered.

But improvements and refinements of the data on each card have been continally in progress. The first printed cards contained little information other than the author's name, the title, and the imprint. There were no subject listings. By 1902 some improvements had been made in collation and the present card numbering system had been adopted. By 1920 books were being cataloged under the ALA rules of 1908, and the cards themselves contained subject entries as well as some other data. The cards of 1945 and later contain refinements both in bibliographical and descriptive data. Subject entries are indicated by Arabic numerals and added entries are indicated by Roman numerals.

From 1902 to the present time, the LC call number has been printed on each card. Since 1930 a Dewey classification number (except in a few such categories as fiction or law) has been printed. The 1952 cards carry two Dewey numbers-those of both the 14 th and the 15 th editions. In brackets, immediately below the Dewey number, is given the number of cards printed for that edition of the card.

Within a few years after his appointment as head of the Card Section, Mr. Hastings became the first chief of the Card Division, when it was created. For 37 years his tremendous energies, his infinite capacity for taking pains in matters of the minutest detail, and the broad scope of his vision in planning the Card Division's activities were amply demonstrated. His successors have built upon the strong foundation which he laid.

From two clerks in 1902, the Card Division's personnel has increased to $167 \mathrm{em}$ ployees in 1952 . In 1939 the division was reorganized into a functional body composed of distinct parts with the workers in each unit responsible for a separate part of the total process.

The primary function of the Card Division is, of course, the distribution and sale of LC printed catalog cards. Accordingly, its operations are designed to serve the needs of libraries as they organize their book collections, as they purchase new books which must be made known to their readers through the.card catalog, and as they strive to improve the quality and economy of their catalogs. Though its principal customers, insofar as volume is concerned, are large libraries with well-organized catalogs, the division is giving increasing attention to the organization of catalogs in small public and school libraries as well as to new or growing libraries in business and industrial firms, in technical and scientific laboratories, and in other types of organizations, many of which may be staffed with untrained librarians.

A significant service is supplied through the division's "Subject Orders." Subject specialists interested in current or older books in their own or related fields can, by placing "subject orders," receive printed catalog cards that serve as a basis for bibliographies in their fields of interest. Sub- 
scribers to this service include individuals, libraries of federal agencies, industrial firms, and libraries in foreign countries.

A new service, the printing and distribution of catalog cards for motion pictures and filmstrips, has recently been inaugurated by the Library of Congress. The printed card for motion pictures and filmstrips is the standard size, on Ioo per cent rag paper and contains the name of the picture, the producer, date of release, running time, size of films, notation on sound and color, and, as applicable, credits, a summary of the contents, subjects covered, grade level, and other information essential to a complete cataloging description of the film. The standard space for overprinting or typing subjects or other headings is reserved at the top of the card, and space on the left margin is ample for location notations or other information desired by the user.

These film catalog cards are sold in sets for the individual titles cataloged. A set consists of one main card for identification by title; an additional card with an overprinted heading for each subject that the film covers and each added entry, such as producer, author, and whatever information is necessary for identification of various other approaches to the fully cataloged entry; and two additional cards without overprinted headings, which the purchaser can use for his own identification, special files, or other purposes.

Within the library the Card Division works closely with the Exchange and Gift Division, the Descriptive Cataloging Division, the Subject Cataloging Division, the Catalog Maintenance Division, the General Reference and Bibliography Division, the Copyright Office, and other units of the library. Service to consultants, scholars, and others who are compiling bibliographies is offered through the printed card.
Not all the operations of the division center around the sale and distribution of cards. Bibliographic and processing operations comprise some of its major activities, because many orders for cards are received b. fore the books in question are published or received by the library or while books are still in the processing stages. Card orders are also received for books that the library probably will neither acquire nor catalog. Hence extensive bibliographic and processing investgations comprise some of the most active operations of the division.

The Documents Section serves as the library's principal selection agency for the state and federal documents to be cataloged. The Investigation Unit of the Orders Section is the library's primary agent for recommending and acquiring many current books by checking daily library acquisitions against books lists, publishers' announcements, and other sources listing current publications.

One of the major tasks of the division is the constant review of methods of operation and the search for more efficient procedures, labor and time-saving equipment, and other means of reducing the cost of cards to subscribers. The division must return to the government the cost of its operations, but combined with this necessity is the ideal of eliminating every waste motion or unnecessary expense to the end that subscribers may be effectively served at the lowest possible cost.

It is with what we believe to be a pardonable pride that the Card Division points to its services to specialists, bibliographers, researchers, and scholars generally. It is with humility that we serve the readers of Neosheo, Sheboygan, Tallahassee, Panhandle, Spokane, and in fact the people of America from Canada to the Gulf and from "sea to shining sea." 